\title{
"PELATIHAN KETERAMPILAN PEMBUATAN KERANJANG BUAH DARI BAMBU UNTUK MERINTIS KEWIRAUSAHAAN BAGI MANTAN TENAGA KERJA WANITA DI KECAMATAN LABUAN KABUPATEN PANDEGLANG PROVINSI BANTEN"
}

\author{
Dr. Ajat Sudrajat, M.Pd \\ Fakultas Ilmu Pendidikan Universitas Negeri Jakarta
}

\begin{abstract}
ABSTRAK
Pelatihan Keterampilan Pembuatan Keranjang Buah dari Bambu untuk Merintis Kewirausahaan bagi Mantan Tenaga Kerja Wanita (TKW) di Kecamatan Labuan Kabupaten Pandeglang Provinsi Banten. P2M ini bertujuan memberikan dan meningkatkan keterampilan dalam merintis kewirausahaan bagi Ibuibu TKW dalam Pelatihan Keterampilan membuat Keranjang Buah dari bambu. Program pelaksanaan P2M ini dilaksanakan di Kecamatan Labuan, dalam upaya peningkatan keterampilam tangan dari bambu bagi Ibu-ibu. Metode penelitian ini menggunakan metode deskiptif yang merupakan cara penelitian dengan menggambarkan peristiwa yang ada pada masa sekarang atau yang sedang terjadi dengan pendekatan kualitatif yang pada hakekatnya ingin melakukan eksplorasi pada objek penelitian atau memperoleh gambaran secara mendalam mengenai proses dan hasil P2M, metode ini dipergunakan dengan pertimbangan bahwa hasil dari P2M dapat diketahui secara akurat karena dapat langsung dibandingkan dengan keadaan sebelum diberi perlakuan. Hasil P2M ini menggambarkan penerapan prinsip-prinsip andragogi pada proses pelatihan membuat Keranjang Buah diterapkan sesuai dengan kebutuhan yang dirasakan masing-masing peserta. Pelatihan ini efektif untuk dilakukan karena pembelajaran oleh peserta pelatihan selama proses pelatihan berlangsung mulai dari analisis sampai pada evaluasi melibatkan peserta pelatihannya untuk terlibat terhadap materi pelatihan dan simulasi yang diberikan. Keterlibatan peserta pada proses pelatihan ini membuat mereka termotivasi mengikuti program pelatihan membuat keranjang buah dari bambu sehingga tercapainya tujuan masing-masing peserta pelatihan.
\end{abstract}

Kata Kunci : keranjang buah, tanaman bambu, kewirausahaan, dan keterampilan.

\section{PENDAHULUAN}

P2M ini dilakukan di Kecamatan Labuan, yakni Ibu-ibu mantan Tenaga Kerja Wanita. Mengenai Pendidikan Masyarakat ini, diatur dalam UU. No 20 Tahun 2003 Sisdiknas :

"Pendidikan nonformal meliputi Pendidikan Kecakapan Hidup, Pendidikan Anak Usia Dini, Pendidikan Kepemudaan, Pendidikan Pemberdayaan Perempuan, Pendidikan Keaksaraan, Pendidikan Keterampilan, Pelatihan Kerja, Pendidikan Kesetaraan, sertapendidkan lain yang ditujukan untuk mengembangkan kemampuan peserta didik."

Ibu-ibu mantan TKW di Kecamatan Labuan Kabupaten Pandeglang Provinsi Banten ini sangat menarik dikarenakan banyaknya para ibu yang pergi untuk menjadi Tenaga Kerja Wanita ke negara Arab Saudi, Malaysia, Singapura, Turki. Diharapkan dengan diberikannya pelatihan ini para ibu-ibu yang berada di wilayah Kecamatan
Labuan Kabupaten Pandeglang akan menjadi berkurang untuk menjadi Tenaga Kerja Wanita, sebab diwilayah Kecamatan Labuan tersebut banyak sekali tanaman bambu dan merupakan daerah wisata baik yang berasal dari wisatawan asing atau wisatawan mancanegara sehingga secara tidak langsung memberikan kontribusi positif terhadap ekonomi ibu-ibu mantan Tenaga Kerja Wanita (TKW). Dengan mengadakan kegiatan yang bisa memberikan dampak secara ekonomi pada Ibu-ibu mantan TKW, diharapkan Ibu-ibu tersebut bisa membantu keuangan keluarganya. Selain itu juga bisa berwirausaha membuat keranjang buah bagi Ibu-ibu mantan TKW. Sehingga nantinya kegiatan Ibu-ibu mantan TKW akan bertambah serta berguna bagi Ibu-ibu mantan TKW itu sendiri. Kebutuhan yang dirasakan oleh Ibu-ibu mantan Tenaga Kerja Wanita di Kecamatan Labuan ini adalah sebuah kegiatan yang dapat berwirausaha bagi 
Ibu-ibu mantan Tenaga Kerja Wanita. Sehingga Ibu-ibu bisa membuka usaha sendiri dengan kegiatan tersebut, yang tentu akan berdampak pada peningkatan ekonomi keluarga.

Oleh sebab itu, Narasumber ingin mengadakan sebuah P2M sebagai bentuk pemberdayaan terhadap Ibu-ibu mantan TKW di Kecamatan Labuan. Pelatihan sendiri dapat diartikan sebagai proses membantu orang lain dalam memperoleh skills dan pengetahuan. Dengan demikian, setelah mengadakan pelatihan ini, Ibu-ibu di Kecamatan Labuan ini akan menambah skill dan pengetahuan mereka. Hal ini sangat berhubungan dengan konsep pemberdayaan.

Narasumber merasa program P2M ini sangat tepat dilaksanakan di Kecamatan Labuan karena wilayah tersebut merupakan kawasan daerah wisata artinya bahwa setelah diadakan pelatihan mereka Ibu-ibu mantan Tenaga Kerja Wanita dapat mengaplikasikan apa yang mereka dapatkan di pelatihan tersebut yaitu membuat keranjang dari bambu yang nantinya dapat di jual kewisatawan domestic dan mancanegara dengan harga yang bervariasi yaitu dengan harga Rp.15.000-Rp.25.000 sesuai dengan bentuk dan besar kecilnya keranjang buah.

Kegiatan berwirausaha dari pembuatan keranjang buah ini cukup menjanjikan, karena di setiap momen perayaan atau hari besar, setiap orang pasti membutuhkan keranjang buah untuk dikirimkan ke sanak keluarga. Terutama oleh Ibu-ibu, yang tentunya gemar membuat makanan atau kue-kue, bisa dimasukkan ke toko-toko terdekat untuk dijual kembali. Tentunya ini sangat menguntungkan bagi ibu-ibu TKW di Kecamatan Carita. Apalagi jika keranjang buah yang dibuat itu unik, menarik dan berbeda dari yang lain, maka peluang untuk dijadikan usaha keranjang buah ini sangatlah besar.

Berdasarkan uraian diatas, maka peneliti sangat tertarik untuk mengadakan program $\mathrm{P} 2 \mathrm{M}$ : "Pelatihan Keterampilan Pembuatan Keranjang Buah Dari Bambu Untuk Merintis Kewirausahaan Bagi Mantan Tenaga Kerja Wanita Di Kecamatan Labuan Kabupaten Pandeglang Provinsi Banten”.

Rumusan masalah yang diangkat dalam pelatihan ini adalah: Apakah melalui pelatihan keterampilan pembuatan keranjang buah dari bambu untuk merintis kewirausahaan bagi mantan Tenaga Kerja Wanita di Kecamatan Labuan
Kabupaten Pandeglang Provinsi Banten dapat meningkatkan perekonomian keluarga?

\section{MANFAAT HASIL PELATIHAN}

Hasil pelatihan pembuatan keranjang buah ini diharapkan dapat memberikan masukan kepada berbagai pihak diantaranya sebagai berikut :

1. Bagi Ibu-ibu Mantan Tenaga Kerja Wanita

a. Menciptakan lapangan kerja bagi ibuibu mantan tenaga kerja wanita.

b. Membiasakan ibu-ibu mantan tenaga kerja wanita untuk memanfaatkan lingkungan sekitar yaitu tanaman bambu.

\section{Bagi Kepala Desa Teluk}

a. Mewujudkan program Desa menciptakan lapangan kerja baru bagi masyarakat khususnya bagi ibu-ibu mantan tenaga kerja wanita.

b. Membina lingkungan masyarakat yang mempunyai daya kreatif tinggi.

c. Menciptakan lingkungan desa yang aman dan tentram.

\section{Bagi Camat Labuan}

a. Membiasakan masyarakat tanggap terhadap potensi lingkungan alam di sekitarnya.

b. Wujud pemberdayaan pemerintahan kecamatan terhadap masyarakat

\section{Bagi Dosen}

a. Mewujudkan Tri Darma Perguruan Tinggi khususnya bidang Pengabdian Masyarakat.

b. Sebagai wahana penyaluran ilmu, pengetahuan, dan teknologi.

c. Sebagai wujud kerjasama antara lembaga pendidikan dan masyarakat.

\section{KAJIAN TEORETIK}

\section{Konsep Pelatihan}

\section{a. Pengertian Pelatihan}

Manusia adalah makhluk yang tidak pernah puas. Ketika ia memiliki sesuatu, ia akan mencari sesuatu yang lain untuk menambah kepuasan yang ada dalam dirinya. Mereka akan mencarinya kemanapun demi mencapai kepuasan tersebut. Begitupun dalam hal peningkatan kemampuan, seseorang 
akan mencari segala cara agar kemampuan yang ada pada dirinya bisa bertambah. Untuk menambah kemampuan, seseorang biasanya melakukan segala cara agar bisa mendapatkan kemampuan yang Ia kehendaki. Salah satunya ialah melalui pelatihan.

Pelatihan sendiri memiliki definisi sebagai suatu fungsi manajemen yang perlu dilakukan terus-menerus dalam rangka pembinaan dalam suatu organisasi. Dalam kaitannya dengan pendidikan, pelatihan sangat diperlukan agar seseorang bisa terus mengasah dan meningkatkan pengetahuan, keterampilan dan sikap yang ada dalam diri seseorang.

Menurut Robinson (dalam Saleh Marzuki, 2010:174) dalam buku Pendidikan Nonformal Dimensi Keaksaraan, Pelatihan dan Andragogi menyatakan bahwa pelatihan adalah pengajaran atau pemberian pengalaman kepada seseorang untuk mengembangkan tingkah laku (pengetahuan, skill, sikap) agar mencapai sesuatu yang diinginkan. Dalam buku ini dijelaskan bahwa dengan mengadakan sebuah pelatihan, seseorang akan mendapatkan pengalaman baru dan keterampilan baru. Selain itu, pelatihan juga bisa mencapai tujuan yang dikehendaki oleh seseorang.

Dari definisi-definisi yang telah diuraikan diatas, dapat disimpulkan bahwa pelatihan adalah proses kegiatan pemberian pengalaman atau pengajaran yang dilakukan secara terus-menerus kepada seseorang untuk menambah dan meningkatkan pengetahuan, pengalaman, skill dan sikap seseorang. Pelatihan yang dilakukan secara terus-menerus dan berkesinambungan akan lebih bermanfaat bagi seseorang dalam hal peningkatan pengetahuan, pengalaman, skill dan sikap yang dimiliki. Dengan demikian seseorang akan menjadi pribadi yang lebih baik lagi.

\section{b. Fungsi Pelatihan}

Setiap kegiatan pasti memiliki fungsi. Fungsi ini digunakan untuk mengetahui sejauh mana kebermanfaatan dari sebuah kegiatan yang dilakukan. Begitupun dengan pelatihan, pelatihan memiliki fungsi yang berguna bagi peserta pelatihan itu sendiri. Berikut adalah fungsi-fungsi dari pelatihan:

a) Pelatihan berfungsi memperbaiki perilaku kerja para peserta pelatihan.

b) Pelatihan memiliki fungsi edukatif

c) Pelatihan memiliki fungsi personal

Ketiga fungsi itu sangat bermanfaat bagi peserta pelatihan. Fungsi pertama yaitu memperbaiki perilaku kerja peserta pelatihan. Maksudnya adalah bahwa Pelatihan berfungsi untuk memperbaiki perilaku seseorang. Perilaku yang dikembangkan adalah kognitif, afektif dan psikomotorik. Ketiga aspek itulah yang akan dirubah dalam sebuah pelatihan, karena dalam zaman sekarang ini dituntut seseorang yang memiliki nilai lebih dibandingkan dengan orang lain. Oleh karena itu, dengan adanya pelatihan seseorang dapat meningkatkan keahlian, pengetahuan dan juga sikapnya.

Fungsi kedua yaitu pelatihan memiliki fungsi edukatif, yaitu bahwa pelatihan berfungsi untuk meningkatkan kemampuan profesional, kepribadian, kemasyarakatan, berkomunikasi dan lain-lain seseorang dengan baik. Pelatihan berfungsi untuk mengarahkan atau membimbing peserta pelatihan kearah sana. Setelah mengikuti pelatihan, diharapkan adanya peningkatan pengetahuan seseorang terhadap suatu bidang. Dengan begitu pengetahuan seseorang akan bertambah dan memiliki nilai lebih dari orang lain.

Fungsi ketiga yaitu pelatihan memiliki fungsi personal, yaitu bahwa pelatihan menekankan pada pembinaan kepribadian dan bimbingan personal untuk mengatasi kesulitan dan masalah hidup. Selain untuk meningkatkan pengetahuan, sikap dan keterampilan, pelatihan juga dapat berfungsi sebagai problem solver dari sebuah masalah. Contohnya ketika banyaknya anak-anak yang tidak berkelakuan baik, maka diadakanlah pelatihan parenting atau pola asuh orang tua terhadap anak. Maka, dengan adanya sebuah pelatihan, kemampuan seseorang untuk mengatasi sebuah 
masalah dapat ditumbuhkan sehingga masalahmasalah yang ada bisa diatasi.

\section{c. Manfaat Pelatihan}

Pelatihan dilaksanakan dengan harapan dapat memetik manfaat dari kegiatan pelatihan tersebut. Dengan melakukan pelatihan, diharapkan banyak manfaat yang dapat dipetik oleh peserta pelatihan. Beberapa manfaat dari sebuah pelatihan adalah sebagai berikut :

1) Pelatihan merupakan alat untuk memperbaiki penampilan kemampuan individu atau kelompok dengan harapan memperbaiki performan organisasi.

2) Keterampilan tertentu diajarkan agar para karyawan dapat melaksanakan tugas-tugas sesuai dengan standar yang diinginkan.

3) Pelatihan dapat memperbaiki sikapsikap terhadap pekerjaan, terhadap pimpinan atau karyawan.

4) Memperbaiki standar keselamatan

Dari manfaat pelatihan diatas, dapat disimpulkan pelatihan bermanfaat dalam hal peningkatan performansi seseorang dalam sebuah pekerjaan atau organisasi. Dengan adanya pelatihan, seseorang bisa mengukur kemampuan dirinya dalam melakukan suatu pekerjaan. Sehingga tujuan-tujuan organisasi ataupun pekerjaan yang diinginkan dapat tercapai dengan baik.

\section{d. Langkah-Langkah Pelatihan}

Menurut Gary Dessler, pelatihan memiliki lima langkah, yaitu sebagai berikut :

a. Analisis Kebutuhan, yaitu: kebutuhan calon yang akan dilatih, dan mengembangkan pengetahuan khusus yang terukur serta tujuan prestasi

b. Merencanakan Instruksi, yaitu: untuk memutuskan, menyusun dan menghasilkan isi program pelatihan, termasuk buku kerja, latihan dan aktivitas yang digunakan.

c. Langkah Validasi, yaitu: langkah dimana orang-orang yang terlibat membuat program pelatihan dengan menyajikannya kepada beberapa pemirsa yang dapat diwakili.

d. Menerapkan Program, yaitu: melatih sasaran yang ditargetkan

e. Langkah Evaluasi, yaitu: manajemen menilai keberhasilan atau kegagalan program ini.

\section{Hakikat Keranjang Buah}

\section{a. Pengertian Bambu}

Dalam kehidupan sehari-hari kita sering menjumpai pohon bambu, baik itu yang ada di kebun maupun yang berada di pekarangan rumah seseorang. Pohon bambu biasanya dikaitkan dengan mitos yang kurang mengenakkan, yaitu banyak masyarakat yang menganggap bahwa pohon bambu itu berhantu. Padahal pohon bambu memiliki banyak sekali manfaat yang bisa kita ambil dari pohon bambu.

Bambu adalah sumber daya alam yang banyak dimanfaatkan oleh karena memiliki sifat-sifat yang menguntungkan, yaitu batang yang kuat, lurus, tegak, rata, mudah dibelah, mudah dibentuk, mudah dikerjakan dan mudah diangkut. Dari definisi bambu tersebut, dapat dikatakan bahwa bambu merupakan spesies tanaman yang bisa dimanfaatkan oleh manusia dan tentunya menguntungkan bagi manusia yang memanfaatkannya.

Bambu adalah tanaman serba guna kedua setelah pohon kelapa. Semua bagian dari tumbuhan bambu bisa dimanfaatkan oleh manusia. Mulai dari akar bambu, batang bambu, daun bambu dan tunas bambu bisa dimanfaatkan oleh manusia dan bisa digunakan dalam kehidupan sehari-hari.

Berikut adalah kegunaan-kegunaan bagianbagian bambu yang bisa dimanfaatkan:

a. Akar bambu, akar bambu bermanfaat untuk menahan erosi dan mencegah tanah longsor. 
b. Batang Bambu, batang bambu bermanfaat untuk bahan bangunan (tiang bangunan, atap, dinding, lantai dan lain-lain), bahan kerajinan anyaman, alat musik, bahan mebel, bahan baku pembuat kertas, sumpit dan lain-lain.

c. DaunBambu, daunbambubermanfaat untuk membungkus makanan dan bahan obat-obatan

d. Tunas bambu, tunas bambu dapat digunakan sebagai bahan makanan (isi lumpia, sayur rebung, dan lain-lain)

Oleh sebab banyaknya manfaat dari bambu, banyak orang yang memanfaatkannya sehingga hasil dari bambu itu dapat bermanfaat bagi kehidupan sehari-hari mereka. Salah satunya ialah bisa dijadikan sebuah parsel, yang bahan baku pembuatannya adalah bambu. Bambu yang tegak dan lurus itu bisa dijadikan keranjang buah/parsel yang indah dan menarik yang dapat digunakan oleh manusia pada momen-momen tertentu, seperti natal, hari raya dan sebagainya.

Selain itu, dari kerajinan bambu tersebut bisa digunakan sebagai peluang usaha bagi seseorang. Keranjang buah/Parsel tersebut bisa dijual dan dijajakan di pasar atau toko, bisa juga menjual sendiri. Hasil dari penjualan keranjang buah/parsel ini bisa digunakan untuk mencukupi kebutuhan sehari-hari. Jadi, pohon bambu ini memiliki manfaat yang sangat banyak bagi manusia.

\section{b. Jenis-jenis Bambu}

Seperti sudah dijelaskan di atas, bambu memiliki banyak sekali kegunaan. Di Indonesia sendiri terdapat 159 spesies bambu dari 1250 jenis bambu di seluruh dunia. Berikut beberapa jenis bambu yang ada di Indonesia:

1) Arundinaria japonica sieb \& Zuc ex stend ditemukan di pulau Jawa

2) Bambusa Arundinacea ditemukan di pulau Jawa dan Sulawesi

3) Bambusa Balcooa Roxb di Jawa
4) Bambusa Malculata (Bambu tutul) di Bali

5) Bambu Apus (Gigantochloa apus) di Jawa

6) Bambu Kuning (Bambusa Vulgaris)

7) Bambusa Multiplex (Bambu Cendani) di Jawa

8) Bambusa Tulda Monro di Jawa

9) BambusaTuldoides(HaurHejo)diJawa

10) Bambusa Polymorpha Monro di Jawa

\section{c. Cara Membuat Keranjang Buah}

Setelah membahas mengenai bambu, jenisjenis serta manfaatnya, maka selanjutnya ialah membahas salah satu manfaat yang bisa dimanfaatkan oleh manusia, yaitu membuat keranjang buah dari anyaman bambu. Berikut adalah proses pembuatan keranjang buah dari anyaman bambu :

1) Alat pembuatan keranjang buah dari anyaman bambu yaitu:
a) Gergaji
b) Kapak
c) Golok
d) Pisau raut
e) Gunting
f) Paku kecil
g) ember

2) Bahan pembuatan keranjang buah dari anyaman bambu yaitu :
a) Bambu 1 ruas (diameter $10 \mathrm{~cm}$ dan 70 panjang $\mathrm{cm}$ )
b) Wantek
c) Lem Fox
d) Kulit rotan/atau tali plastik

3) Langkah Pembuatan Keranjang Buah

a) Belah ruas bambu, lalu buat tiga iratan dengan lebar $1,5 \mathrm{~cm}$ dan dua iratan sebagai penjepit bingkai atas dan bawah dengan lebar $1 \mathrm{~cm}$. Iratan (bahan anyaman) ini selalu dalam posisi horizontal. Buat pula iratan anyaman dengan panjang $6 \mathrm{~cm}$ dan lebar $1 \mathrm{~cm}$. Iratan ini dalam selalu posisi vertical. 
b) Ambi ketiga iratan horizontal dan susun belajar diatas permukaan yang rata. Satu persatu iratan vertical dianyam berselang-seling. Pertama, ditindih iratan horizontal di bagian atas dan bawah, sedangkan bagian tengah menindih atau berada di atas iratan horizontal. Lakukan hal serupa, tetapi dengan cara sebaliknya. Yakni irisan horizontal menindih di atas dan bawah, sementara bagian tengah ditindih atau berada di bawah iratan horizontal. Jarak antara iratan vertical $1 \mathrm{~cm}$.

c) Setelah mencapai panjang anyaman yang diinginkan, sambungkan kedua ujung anyaman dengan mengikatnya menggunakan kulit rotan/tali plastik. Kini anyaman berbentuk bulat telur.

d) Siapkan anyaman penutup dasar/ alas keranjang. Cara menganyam dengan sistem dua-dua. Sesuaikan bentuk dengan ukurannya.

e) Pasang dua bilah penjepit untuk menyatukan alas dan dinding keranjang. Lalu, ikat dengan tali rotan/tali plastik pada sela-sela iratan. Lakukan hal serupa untuk bagian atas keranjang.

f) Untuk memperindah penampilan sekaligus memperkokoh keranjang maka jahit dinding keranjang dengan kulit rotan/tali plastik. Lalu anyaman pegangan dengan menyatukan anyaman rantai.

g) Bersihkan keranjang dari sisa iratan yang menyembul dengan gunting atau kompor tekan. Vernis seluruh bagian keranjang dan keringkan.

\section{MATERI DAN METODE}

\section{A. PELAKSANAAN KEGIATAN}

\section{Realisasi Pemecahan Masalah}

Pelaksanaan pelatihan Keterampilan Pembuatan Keranjang Buah Dari Bambu Untuk Merintis Kewirausahaan Bagi Mantan Tenaga Kerja Wanita Di Kecamatan Labuan Kabupaten Pandeglang Provinsi Banten".

Pelatihan keterampilan pembuatan keranjang buah ini dilaksanakan di Kantor Desa Teluk Kecamatan Labuan Kabupaten Pandeglang. Pelaksanaan keterampilan ini melibatkan 2 orang dosen UNJ. Pelaksanaan kegiatan ini dilakukan selama 1 hari.

Pembagian jadwal dalam pelatihan ini adalah sebagai berikut:

a. Konsep pelatihan dan kewirausahaan disampaikan oleh: Dr. Ajat Sudrajat, M.Pd.

b. Praktek pembuatan keranjang buah disampaikan oleh: Drs. Supria Wiganda, M.Pd.

Berdasarkan usulan yang diajukan, maka materi kegiatan utama pengabdian ini adalah:
a. Pelatihan/kewirausahaan pembuatan keranjang buah.
b. Praktek pembuatan keranjang buah.

\section{Khalayak Sasaran}

Sasaran kegiatan pengabdian kepada masyarakat ini adalah ibu-ibu mantan Tenaga Kerja Wanita kurang lebih 30 orang di Kecamatan Labuan Kabupaten Pandeglang Provinsi Banten.

Pelatihan pembuatan keranjang buah ini sebagai upaya untuk meningkatkan pendapatan keluarga bagi ibu-ibu mantan tenaga kerja wanita dan dapat menciptakan peluang serta pada akhirnya meningkatkan Pendapatan asli wilayah Kecamatan Labuan Kabupaten Pandeglang Provinsi Banten. 


\section{B. METODE PENERAPAN IPTEKS}

Untuk mencapai tujuan yang telah ditetapkan, maka metode pelatihan pembuatan keranjang buah yang akan digunakan adalah: Metode ceramah dan metode praktik. Penyajian teori tentang pelatihan praktik pembuatan keranjang buah diberikan dalam bentuk ceramah. Metode ceramah ialah suatu cara penyajian bahan pelajaran dengan melalui penuturan (penjelasan lisan) oleh narasumber kepada peserta pelatihan. Metode ceramah bervariasi merupakan cara penyampaian, penyajian bahan pelajaran dengan disertai macam-macam penggunaan metode pengajaran lain.

Sedangkan contoh pembuatan keranjang buah dilaukan melalui metode pratik secara langsung sesuai dengan materi yang akan disampaikan kepada peserta. Melalui kegiatan praktik langsung diharapkan peserta/ibu-ibu mendapatkan pengalaman melalui interasi langsung dengan objeknya. Praktik langsung adalah proses belajar mengajar yang dilakukan oleh guru dengan cara melakukan praktek secara langsung sesuai dengan materi yang akan disampaikan kepada peserta pelatihan.

\section{HASIL PELATIHAN}

Hasil yang dicapai adalah setiap peserta pelatihan pembuatan keranjang dari bambu untuk merintis kewirausahaan bagi mantan tenaga kerja wanita adalah para ibu-ibu dapat membuat keranjang buah dengan berbagai variasi dan motif sehingga dapat meningkatkan pendapatan keluarga para ibu-ibu di Desa Teluk Kecamatan Labuan Kabupaten Pandeglang Provinsi Banten.

\section{EVALUASI}

Untuk melihat efektivitas pelaksanaan pelatihan ini, maka dilaksanakan evaluasi. Evaluasi yang dilaksanakan adalah evaluasi proses dan evaluasi hasil. Tolok ukur dari evaluasi proses adalah peserta pelatihan dapat menerapkan pembuatan keranjang buah di lingkungan tempat tinggal para ibu mantan Tenaga Kerja Wanita. Sedangkan tolok ukur evaluasi hasil adalah setiap ibu-ibu dapat memanfaatkan tanaman bambu yang ada dilingkungan wilayah kecamatan labuan sebagai bahan dasar pembuatan keranjang buah.

Selain evaluasi proses dan evaluasi hasil, dilakukan juga evaluasi pelaksanaan pelatihan dengan menggunakan instrumen. Instrumen yang digunakan membahas mengenai manfaat dari pelatihan baik manfaat terhadap peserta. Untuk keperluan analisis, pilihan pernyataan diberikan skor 1-4 yakni berturut-turut untuk tanggapan Sangat Tidak Setuju (STS), Tidak Setuju (ST), Setuju (S), dan Sangat Setuju (SS). Apabila peserta tidak memilih pernyataan yang disediakan diberi skor nol (0).

\section{HASIL DAN PEMBAHASAN}

\section{A. DESKRIPSI DATA}

Kegiatan ini diikuti oleh 20 peserta ibu-ibu mantan tenaga kerja wanita yang terdiri dari berbagai tujuan tempat tenaga kerja wanita.

Kegiatan pelatihan ini bertempat di kantor desa Teluk kecamatan Labuan Kabupaten Pandeglang, yang dilaksanakan pada tanggal 1 September 2016. Pelatihan ini dilakukan dengan 2 cara, yaitu:1) pemberian teori hakikat dan makna pelatihan pembuatan keranjang buah. 2) pelaksanaan praktik, pada pelaksanaan ini ibuibu langsung praktik pembuatan keranjang buah.

\section{B. HASIL DAN PEMBAHASAN}

\section{Hasil pelatihan}

Pelatihan adalah suatu kegiatan yang bertujuan untuk mengembangkan dan mencapai efektivitas pekerjaan perorangan yang lebih besar, hubungan antara pribadi dalam organisasi yang lebih baik an menyesuaikan pemimpin kepada konteks seluruh lingkungannya. Hal ini senada dengan ungkapan dari Andrew E Sikula bahwa pelatihan adalah suatu proses pendidikan jangka pendek memanfaatkan prosedur yang sistematis dan terorganisir, dimana persoalan non manajerial mempelajari kemampuan dan pengetahuan teknis untuk tujuan tertentu.

Tujuan pelatihan :

1. Meningkatkan keterampilan para ibuibu mantan Tenaga Kerja Wanita

2. Meningkatkan produktivitas kerja para ibu-ibu mantan Tenaga Kerja Wanita.

3. Meningkatkan wawasan kepada para ibu-ibu mantan tenaga Kerja Wanita dalam mengerjakan pembuatan keranjang buah. 
4. Meningkatkan kemampuan menginterpretasi data dan daya nalar para ibu-ibu dan kemampuan serta keterampilan para ibu-ibu dalam pembuatan keranjang buah.

Sedangkan manfaat pelatihan adalah :

1. Menambah wawasan dan pengetahuan tentang pembuatan keranjang buah dari bambu.

2. Menambah keahlian tertentu khusus dalam pembuatan keranjang buah

3. Menambah keuangan keluarga.

\section{Pembahasan hasil Pelatihan.}

Dalam pelaihan ini yang dilaksanakan pada tanggal 1 September 2016, materi yang disampaikan dilakukan melalui 2 cara, yaitu: Pertama, pemberian teori tentang hakikat pelatihan. Kedua, praktek langsung pembuatan keranjang buah, dimana narasumber memberikan masingmasing alat peraga kepada ibu-ibu mantan Tenaga Kerja Wanita yaitu bambu berupa sisitan-sisitan yang sudah rapih untuk digunakan dalam pembuatan keranjang buah.

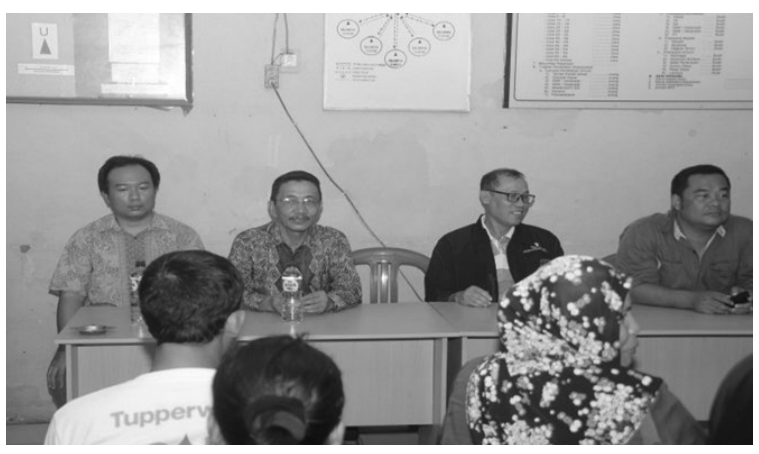

Gambar 1 : Pembukaan pelaksanaan Pengabdian Kepada Masyarakat Lembaga Pengabdian Masyarakat Universitas Negeri Jakarta yang dibuka oleh Camat Labuan yaitu Agus Riyanto, S.Sos.

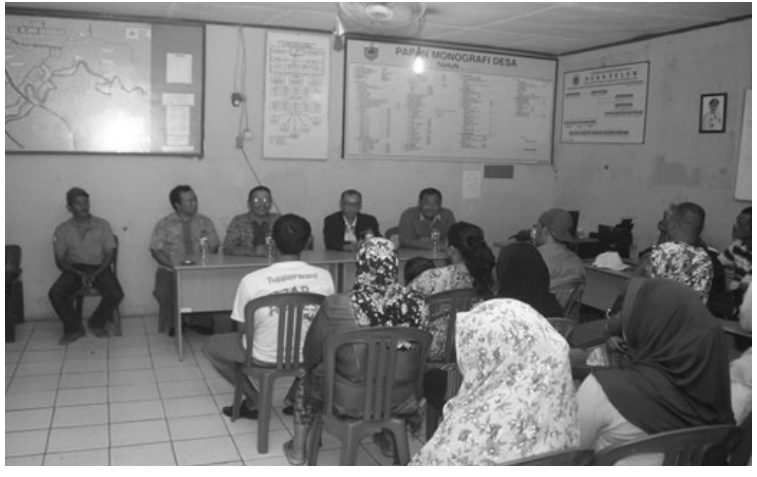

Gambar 4: Suasana pembukaan pelatihan

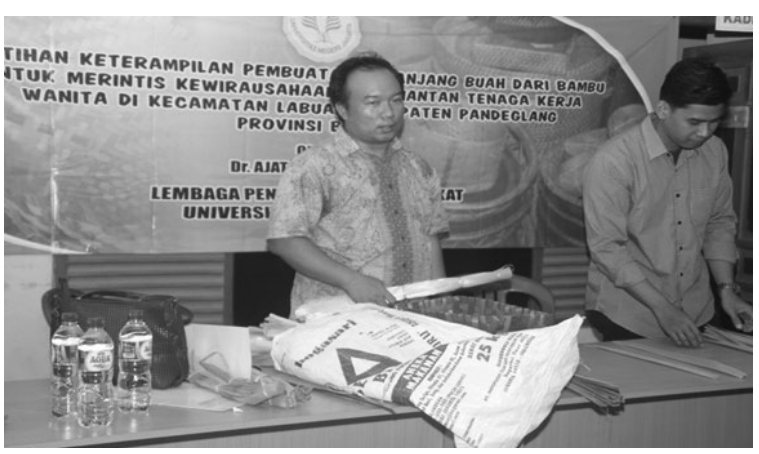

Gambar 5: Narasumber sedang menjelaskan hakikat pelatihan keranjang buah bagi mantan tenaga kerja wanita

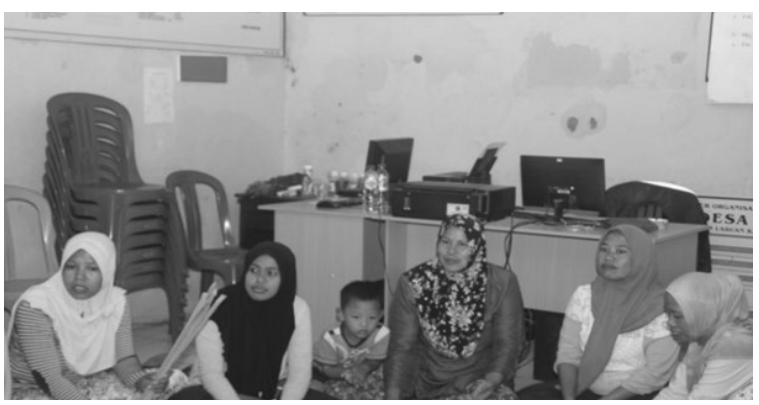

Gambar 6: ibu-ibu Peserta sedang memperhatikan penjelasan dari Narasumber tentang hakikat pelatihan keterampilan pembuatan keranjang buah dari bambu

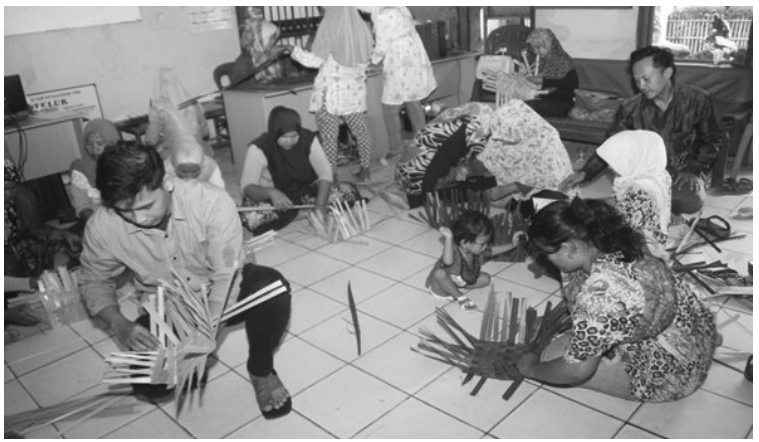

Gambar 10: Peserta sedang membuat keranjang buah dari bambu 


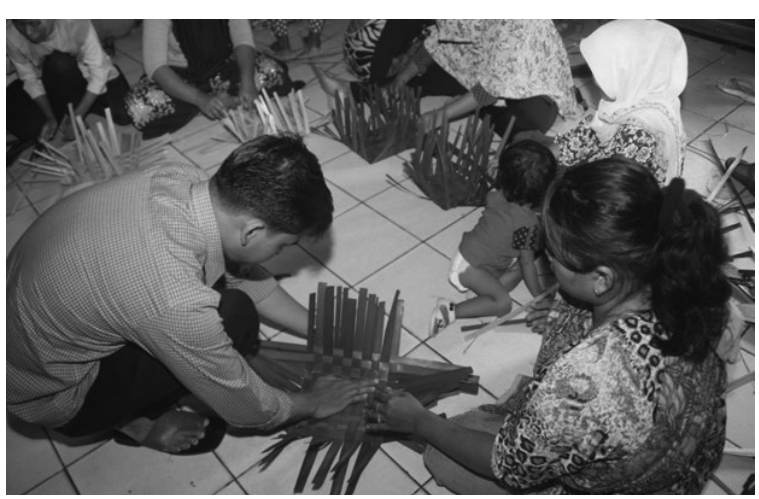

Gambar 11 : Peserta sedang membuat keranjang buah dari bambu

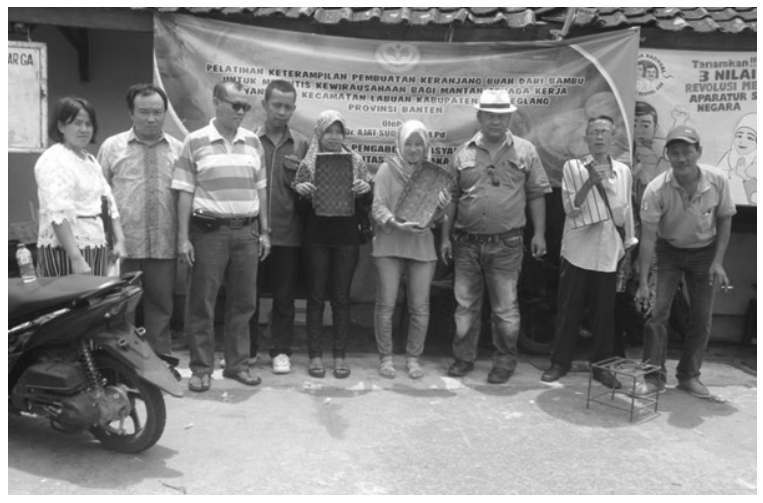

Gambar 12: Narasumber, Kepala desa dan peserta sedang menunjukkan hasil pembuatan keranjang buah

Harapan yang ingin dicapai oleh narasumber adalah peserta/ibu-ibu para mantan tenaga kerja wanita dalam membuat keranjang buah dari bambu adalah salah satu cara keluarga dalam merintis kewirausahaan yang mandiri dan kreatif. Disamping itu di tunjang oleh tanaman bambu yang sangat melimpang di wilayah tersebut sehingga mudah didapat dari bahan baku-nya, dengan para ibu-ibu mantan tenaga kerja wanita mengikuti pelatihan ini diharapkan juga pada akhirnya dapat meningkat usaha micro dan tentunya meningkatkan pendapatan keluarga secara berkesinambungan.

\section{PENUTUP}

\section{A. KESIMPULAN}

Dari hasil "Pelatihan Keterampilan Pembuatan Keranjang Buah Dari Bambu Untuk Merintis Kewirausahaan Bagi Mantan Tenaga Kerja Wanita Di Kecamatan Labuan Kabupaten Pandeglang Provinsi Banten", adalah :
1. Pelatihan keterampilan membuat keranjang buah dari bambu diharapkan dapat meningkatkan jiwa kewirausahaan bagi mantan Tenaga Kerja Wanita

2. Pelatihan keterampilan membuat keranjang buah dari bambu ini diharapkan dapat meningkatkan sumber pendapatan keluarga.

\section{B. SARAN}

Saran yang diajukan adalah :

1. Perlu diadakannya pelatihan yang serupa sehingga munculnya daya kreatifitas para ibu-ibu mantan tenaga kerja wanita.

2. Perlu nya pemanfaatan tanaman bambu yang efektif untuk meningkatkan kesejahteraan masyarakat sekitar.

3. Pemerintah kecamatan hendaknya mempunyai visi dan misi yang tepat disesuaikan dengan kondisi alam lingkungan.

\section{DAFTAR PUSTAKA}

Andi Mappiare, Psikologi Orang Dewasa, (Surabaya : Usaha Nasional, 1983) hlm. 17

Ari Fadianti. Menjadi Wirausaha Sukses. Remaja Rosdakarya. 2011. Hal15.

Alamendah. 2011. Jenis-jens Bambu di Indonesia. Diakses pada 05 Maret 2013 dari http://alamendah.wordpress.com/2011/01/28/ jenis-jenis-bambu-di-indonesia/

E. Manuhuwa. 2009. Pengertian dan Definisi Bambu. Diakses pada tanggal 05 Maret 2013 dari http://pengertian-Definisi.blogspot.com/2013 01_01_archive.html

Gary Dessler. Manajemen Sumber Daya Manusia. PT Indeks. 2008. Hal 281

Saleh Marzuki. Pendidikan Nonformal Dimensi dalam Keaksaraan Fungsional, Pelatihan, dan Andragogi. Remaja Rosdakarya. 2010.Hal 175.

Suryana. Kewirausahaan Pedoman Praktis, Kiat dan Proses Menuju Sukses. Salemba Empat. 2003.hal 2

Undang-Undang Republik Indonesia Nomor 20 Tahun 2003 Sisdiknas. 2006. Fokus Media. Hal 2.

Oemar Hamalik. Pengembangan Sumber Daya Manusia Manajemen Pelatihan Ketenagakerjaan Pendekatan Terpadu. Bumi Aksara. 2005. hlm. 10. 